\title{
Research and Education in Taiwan
}

\begin{abstract}
Anne E. Egger, Math/Science Department, San Juan College, 4601 College Blvd., Farmington, New Mexico 87402, eggera@sanjuancollege.edu
\end{abstract}

I found my seat in the DC-10, grateful to have collected enough air miles in the past year to qualify for the "Economy Plus" section and five more inches of legroom. The passenger in the seat next to me pulled out a few familiar items: a schedule, a stack of papers to grade. I turned to him and said, "Are you on your way to the Penrose Conference, by any chance?"

He confirmed my suspicions. We introduced ourselves, and, not recognizing my name, he said, "You must be from the tectonics end of things."

"Well, sort of," I replied. "I'm actually attending this meeting as an educator."

He looked surprised, so I elaborated. "I teach geology at a community college in New Mexico. I'm a structural geologist, too, but the interdisciplinary nature of this topic could provide some great educational opportunities."

"Oh," he said. "Wow. Good luck."

We chatted occasionally over the next 13 hours or so until the plane touched down in Taipei, Taiwan. Then he took a cab and I took a bus to the hotel.

My attendance at the "Tectonics, Climate, and Landscape Evolution" Penrose Conference in Taiwan in January 2003 was something of an experiment. Penrose Conferences, as most GSA members are aware, are typically subject-specific work sessions for researchers who share interests or, in this case, approach similar problems from a wide range of backgrounds. To explore the relationships between tectonics, climate, and landscape evolution, the conveners had accepted applications from meteorologists, geophysicists, structural geologists, geomorphologists, experi-

mental sedimentologists, and GIS experts from all over the world. The topic immediately caught my eye-few things appeal to me more as a teacher than the chance to connect several concepts together into an interdisciplinary exploration. Many scientists and educators have made these broad connections before: plate tectonics built the Cascades, for example, which create a long rainshadow in eastern Oregon, where a daunting desert landscape looks more like Nevada than the Oregon coast. The chance to explore these interactions in more detail with experts was compelling.

Having made a choice to teach at a community college rather than to pursue a research career, I had little to contribute to the conference. Community college instructors generally teach 15 credit hours per semester (four to five classes), leaving little time for research and often making it difficult to stay current within their discipline. There is no chance to teach higher level classes, as the students who would potentially take those courses have transferred to four-year colleges by that time. I thought I might be able to experience the excitement of

Their response overwhelmed me - they asked if I would like to attend the conference to do just that.

the conference vicariously, though, and contacted the conveners to see if they had plans for creating any educational materials as a result of the conference. Their response overwhelmed me-they asked if I would like to attend the conference to do just that.

I leapt at the chance. We agreed on the details of what I would do there and arranged funding that would enable my travel.

Unsure what to expect, I anticipated one main outcome: I would collect a pile of material about tectonics, climate, and landscape evolution to be repack- aged for a non-specialist audience. At the end of ten days in Taiwan, it was clear that I had underestimated the possibilities. There was no shortage of content, and my notebook quickly filled with detailed notes, names and URLs, and thoughts for educational materials. But two unanticipated results also surfaced: a highly enlightening and ongoing discussion about how we do science, and the collection of a whole host of good ideas and problems concerning earth science education.

The interdisciplinary nature of the content of the meeting created an ideal atmosphere for the discussion of education, in no small part because of the logistics involved in bringing meteorologists, structural geologists, and geomorphologists together into the same room-there was a lot of educating to do. Our field trip through the central mountains of Taiwan to look at the change in metamorphic grade and fabric across the crest, for example, included an impromptu (and oft-repeated) lecture by Ron Smith on the foehn (say "fern") cloud spilling over the divide. Presentations were geared toward the non-specialist, and presenters took time to explain what they may have considered basic concepts before delving into the details of their work. No one was embarrassed to ask, "What is $e$ ?" or "What does that mean?" Throughout the conference, language was very important-words used in one sense in one discipline had to be clarified for people in other disciplines who used them differently. This confusion reflects a common situation in the classroom, when students misunderstand the word "theory" or "error," for example, leading them to draw inaccurate conclusions about the general acceptance of plate tectonic theory.

The conference also offered an amazing amount of insight into how scientists educate themselves and how they pursue education in the classrooms where they teach. Most university science faculty are chagrined when their students do not recognize that science is not a collection of facts and figures, but an ongoing series of ques- 
tions. These same faculty may be uncomfortable sharing their own experiences in the classroom-that they spent a year building an experimental apparatus that didn't work, or that the results of their research were completely unanticipated and caused a shift in focus. But this is how we do science. We do field work, we experiment, we model, we collect samples, we start out asking one question and find out it's not the right one. This is a fundamental aspect of science that we often forget when we are standing in front of an introductory geology class. But the process of science is just as important as the explanations that come out of the process.

People told me about great things they had done in their classrooms and problems they were having in their departments. Many schools are shifting from "geology" departments to "earth science" or "earth system science" departments, often forcing faculty to teach more interdisciplinary courses. Several people told me about the innovative, problem-based classes they had designed to fulfill this need.

Possibly the most frequently cited problem was gender. Out of $100+$ participants in the Taiwan conference, there were eight women, half of whom were graduate students. This ratio accurately reflects the faculty gender ratios in many earth science departments, but graduate student ratios have been close to 50:50 for more than a decade. What is happening? This article is not the place to explore this question, but concerns were raised that it may relate to the method of education or the perception of life as a tenure-track research faculty member.

Amidst the wide range of conversations about these topics, I began to realize just how unlikely and unusual my presence in Taiwan was. There are few resources available for community college faculty to pursue or stay involved in research, and few reasons to do so. Unlike at four-year institutions, there is no tenure carrot at the end of the research stick. It is a challenge to find time to write grant proposals, much less to actually perform the research, when teaching four classes per semester without teaching assistants or graduate students. Travel grants and discounted meeting registration generally are usu- ally available only to K-12 educators. These factors leave many college science faculty whose focus is on teaching out of the research loop and hardpressed to stay current.

Yet most scientists agree that integrating ongoing research into teaching is a critical component of science education at all levels, especially the college level. And $44 \%$ of all undergraduates in the U.S. are enrolled at community colleges. Did you get that? Nearly half of all of the students pursuing undergraduate degrees in the U.S. are doing so at community colleges. Full-time tuition at community colleges averages $\$ 1,300$ per year, and is by far the most affordable higher education available. And yet this year, as state budgets fell short and federal funds diminished, many community colleges were the first to feel the heat.

GSA is expertly prepared to provide a forum for the presentation of research through its annual and sectional meetings and publications. It facilitates student research through its student grants and promotes ongoing research through Penrose Conferences and field trips. Recently, the Education \& Outreach Department of GSA has begun to collect and publish educational materials for K-12 educators on its Web site. But I must ask: How many GSA members are $\mathrm{K}-12$ educators? The materials available on the Web site represent a tremendous amount of work and dedication, but so far, little has been done to reach out to college-level educators, who are the majority of GSA members.

Granted, a lot of opportunities for professional contributions in geoscience education exist. There are geoscience education technical sessions at GSA meetings. The National Association for Geoscience Teachers (NAGT) publishes the Journal of Geoscience Education, where many faculty find an outlet for peer-reviewed papers about teaching methods, classroom success stories, and innovative ideas. NAGT also offers field camp scholarships to a small number of qualified undergraduate students. The Digital Library for Earth Science Education (DLESE) has done a fantastic job of reviewing and compiling appropriate websites for classroom use. The Geoscience Education program within the National Science Foundation funds the best proposals that integrate geosci- ence research and education.

But something is missing. Where GSA could truly take a leading role is in the granting of funds to college-level educators, at both four- and two-year institutions, to pursue and promote professional development and short-term educational goals. Ideally, GSA would develop a program similar to the existing student research grants but intended instead for college faculty to develop curricular materials, attend research meetings (at which they are NOT presenting research) to stay current, and pursue educational research within their geoscience classrooms. None of these goals requires huge sums of money, so the size of the student research grants (averaging \$1,800) would be appropriate. Money doesn't fall out of the sky, of course, especially when teachers are the ones asking for it, but donations could be sought in a format similar to the GSA Foundation. Additionally, GSA could provide space on its Web page for the archiving of educational materials generated through these small grants. This may expand to include appropriate materials presented at technical sessions, reviewed through an existing process like that used by DLESE.

Attending the Penrose Conference was an incredibly valuable experience for me both as a geologist and as an educator - an experience that I believe should be available to more college faculty who are primarily teachers. I would argue that my presence was equally important for the other participants who shared their content, insights, and concerns with me. Everyone present was concerned about education, whether it was their own or their colleagues', their students' or policy makers'. We are obliged to stay current not only to be competitive in our research, but in order to convey the excitement of research to our students. I hope my experimental trip to Taiwan will not stand alone, and similar ventures will become not only common, but an essential element of geoscience education and outreach.

An upcoming GSA Special Paper will collect the work of the presenters and attendees of "Tectonics, Climate, and Landscape Evolution," a Penrose Conference beld in Taiwan in January 2003. 